\title{
Manually operated pile driver for use in the south Iraqi Marshlands
}

\author{
Massimo Monti, Giuseppe Rossi, Stefano Simonini, Francesco Sorbetti Guerri, \\ Matteo Barbari \\ Dipartimento di Gestione dei Sistemi Agrari, Alimentari e Forestali (GESAAF), Sezione Ingegneria \\ Agraria, Forestale e dei Biosistemi, Università di Firenze, Firenze, Italy
}

\begin{abstract}
Anthropizations are necessary to implement the maintenance, recovery and utilization of wetlands. These interventions should be sustainable in every sense, in particular they should be marked by a low environmental impact. In general this aim can be achieved by using natural materials and carrying out procedures minimally invasive. In Developing Countries the latter point is often supported by the lack of equipment and energy availability, normally obtainable in Industrialized Countries. In practice, to build micro-infrastructures with the above said characteristics, it is normally necessary to drive poles, in our case in wood, in marshland's soil. In order to accomplish this task a manually operated pile driver was designed and built. To operate in the water, a floating pier consisting of removable modular elements was also designed.
\end{abstract}

\section{Introduction}

\section{Aim of the work}

The aim of this work is to design, build and make actually executive tools and methods of use that would allow the construction, in appropriate ways, of micro-infrastructures necessary to wise-use of wetlands. These tools and ways to operate should be sustainable. Such characteristic is essential particularly in developing Countries, both from the environmental point of view and from the economic-social one.

Correspondence: Matteo Barbari, Dipartimento di Gestione dei Sistemi Agrari, Alimentari e Forestali (GESAAF), Sezione Ingegneria Agraria, Forestale e dei Biosistemi, Università di Firenze, Italy.

E-mail: matteo.barbari@unifi.it

Key words: wood pile driver, floating pier, wetland ecosystems, Marshlands, Iraq.

Acknowledgments: study carried out within the project funded by Italian Ministry of Foreign Affairs - DGCS Task Force Iraq, titled "Rational management of water resources for agricultural development of rural areas in South Iraq".

(C) Copyright M. Monti et al., 2013

Licensee PAGEPress, Italy

Journal of Agricultural Engineering 2013; XLIV(s2):e170

doi:10.4081/jae.2013.s2.e170

This article is distributed under the terms of the Creative Commons Attribution Noncommercial License (by-nc 3.0) which permits any noncommercial use, distribution, and reproduction in any medium, provided the original author(s) and source are credited.

\section{Wetland ecosystems}

Worldwide wetlands are areas with a very high conservation value, significantly contributing to human well-being. In these areas water is the primary factor to control environment and associated plant and animal life. Wetland ecosystems are essentials for the conservation of the biodiversity . Article 1.1 of the Ramsar Convention officially defines "Wetlands".

More than three billion people (around half the world's population) obtain their basic water needs from inland freshwater wetlands. A similar number of people rely on rice as their staple food, a crop largely growing in natural and artificial wetlands. In some parts of the world, such as the Kilombero Wetland in Tanzania, almost the entire local population relies on wetland cultivation for their livelihoods .

Throughout history, in many places, a lot of attempts to "reclamation" have been carried out, that is, in this case, to wetlands draining, conversion and destruction, originated by reasons of particularistic, social, political and health nature. More than $50 \%$ of wetlands in North America, Europe, Australia and New Zealand were destroyed during the twentieth century, and many others in many parts of the world degraded (MA, Millennium Ecosystem Assessment, 2005).

To counter these trends, organizations with the mission to protect wetlands are born and developed, giving rise to international and national legislation and regulations (Shine and de Klemm, 1999).

\section{Iraqi Marshlands}

Until a few decades ago the Iraqi Marshlands, having an area of over $20,000 \mathrm{~km}^{2}$, were the largest wetland ecosystem in Western Eurasia (UNEP and Partow, 2001). However, over the past 30 years, they were subject to a gradual drying, which reduced their surface area by about $70 \%$. This drying is due in part to the construction, by neighboring countries, of dams on the rivers, especially the Euphrates, which descend from the mountains of Northern Iraq. But above all the will of Saddam Hussein's Government was decisive to eradicate, and even physically eliminate, Shiite populations gravitating on Marshlands, on which he could not take full control (USAID, 2004; Alwash et al., 2008).

The Marshlands were, and still partly are, inhabited by populations with cultural peculiarities and way of life fully integrated in the marsh environment (Kubba, 2011).

For some years some international projects are in progress to reflood Iraqi Marshlands and revitalize activities linked to them, in order to favor their sustainable development (Eden Again, 2003; AMAR International Charitable Foundation, 2001).

\section{Wise use of wetlands and wustainable anthropizations}

Protected wetlands are often considered as "nature sanctuaries", rather than valuable ecosystems that can also be used sustainably by communities. Nevertheless, in the course of time, in some of these ecosystems a human presence was established, which, in many cases 
and for very long periods, utilized resources from animal and plant environment employing means and methods compatible with the sustainability.

Man, sometimes unconscious of wetlands fragility, in attempt to increase their productivity, has greatly disturbed the natural system, not only severely damaging it, but also causing a productivity decline.

In order to be properly maintained and protected, economically sustainable activities have to be performed in wetlands. They can also provide jobs and livelihood for people living in and around them (Russi et al., 2013). All this goals can be reached by practicing the "wise use".

The wise use of wetlands is defined as "the maintenance of their ecological character, achieved through the implementation of ecosystem approaches, within the context of sustainable development". "Wise use" therefore has at its heart the conservation and sustainable use of wetlands and their resources, for the benefit of humankind (Ramsar Convention on Wetlands, 2010). "Sustainable development" is intended as defined in "Our Common Future" Report (United Nations, 1987).

Wetlands provide a different range of valuable services. In general, merely by their existence, they perform functions such as reduction of the damaging impact of floods, control of pollution and regulation of the climate. Among the many functions that wetlands can perform, those related to direct or indirect productivity are particularly interesting in our study. The following products can be mentioned: fish and timber, wildlife (directly harvested or used indirectly for ecotourism or scientific research purposes), housing materials such as reeds, medicinal plants, agricultural, livestock and pastoral products, water supply for domestic and irrigation (CBD, 2004; UNEP, 2007; Russi et al., 2013; Ramsar Convention on Wetlands; UNWT0, 2012). These products and activities have direct and immediate benefits for local communities and peoples living in or close to wetlands.

All these activities, in order to be carried out, require changes of the nature, even in the slightest degree: namely, small anthropizations are realized. The most important feature of anthropizations, to be consistent with the implementation of a sustainable development, is not so much the small size, as their reversibility. They should be in maximum degree deconstructible (Barbari et al., 2012a). The degree of deconstructibility, which in some cases may reach $100 \%$, essentially depends on the used materials and construction methods. Suitable materials can be considered those of natural origin (wood, reeds, straw, and other fibrous materials mainly made of cellulose, raw earth, stone) and steel, which to some extent is almost always indispensable and, in any case, is a 100\% recyclable material (Barbari et al., 2012 b; Berge, 2001).

Natural materials are often regarded as low-tech or outdated. On the contrary, we want strongly to affirm here that "there are no lowtech or outdated materials, but only low-tech or outdated ways of using them".

Infrastructures, or rather micro-infrastructures, which are necessary for the sustainable use and exploitation of wetlands are, for example: riparian adjustments, small channels dams, landings and moorings, boardwalks, small earth roads, pathways, shelters for boats, shacks, small buildings for the management of activities (fishing, breeding, cultivations, fish farming, pastoralism, bird-watching, etc.) and other anthropizations, which are part of a fully-fledged system of sustainable management of wetlands.

\section{Materials and methods}

\section{Piles}

In wetlands for the construction of all the above-mentioned infrastructures, the placement of piles is always required, specifically wood- en piles or, secondly, steel piles, driven into the soil. The piles serve as foundation, support and anchorage for constructions. These functions can also be provided by other types of structures, for example concrete arrangements, but these are not compatible with sustainability objectives above outlined.

The major criticisms regarding the use of wood can be the difficulty of supplying, because sometimes the wood is not naturally present in the vicinity of the place of use, and the poor durability.

As regards the first aspect, it can be underlined that steel and concrete are never naturally present in the vicinity of the place of use. Given the density/mechanical strength ratio of the materials, it is presumable that the specific transportation environmental impact related to the wood is lower than for the other materials. As regards the second aspect, the durability of the wood depends on the species used and can actually be lower than that of the concrete, which anyway is not unlimited. However, the advantages of the use of wood in relation to sustainability (Barbari et al., 2012b) are such as to justify its use. Moreover timber is widely applied worldwide in wetlands.

The diameter of the wooden piles used for the type of construction considered in this study can vary roughly from $10 \mathrm{~cm}$ to $16-18 \mathrm{~cm}$.

\section{Piles driving}

To drive small diameter piles, such as those here required, in industrialized countries hydraulically or pneumatically operated machineries are generally employed, in which the energy is supplied by a thermal engine. Very popular are the vibratory pile drivers applied to the arm of excavators, pile drivers connected to the power takeoff of farm tractors, pneumatic pile drivers connected to compressors. When the piles have to be driven in submerged soil, the pile drivers should be placed on floating docks.

When operating in ecosystems having high natural value, transportation, placement and operation of pile drivers and of related actuator machinery could lead to serious problems of environmental impact.

In developing countries, and particularly in wetlands, machines of the above type are not usually available. Even if they were, they would have costs that fall outside of the actual economic availability of local populations. In addition, the fragility of ecosystems requires the utmost caution relating to materials and methods used.

For all the above aspects, the use of a manually operated pile driver, hammering body type, can be considered the optimal solution.

This type of pile drivers has a history of millennia and, given that since ancient times a highly efficient technology has been adopted, in the course of time it had no major developments. The model of pile drivers present in the Department GESAAF of University of Firenze (Figure 1) probably is not very different from the machinery used by Julius Caesar to build the bridges on the Rhein river, $55 \mathrm{BC}$ and $53 \mathrm{BC}$.

Today manually operated pile drivers are not produced, with the exception of very small types, which, however, can effectively perform the limited functions to which they are intended.

On the basis of specific needs shown in this paper, the researchers of Department have designed and constructed a manually operated pile driver, and designed a floating pier to build on site.

\section{Design}

\section{Border conditions}

The pile driver and the floating pier have been designed taking into account the below boundary conditions:

The pile driver and the floating pier should be used, and replicated, in areas in which there is, in contrast to industrialized countries, large supply of cheap manpower. In such areas local populations have generally kept the "the art of getting by", ability that, con- 
versely, technological progress has greatly reduced in the "Northern hemisphere".

- The pile driver should be manually operated.

- The materials used in construction should be readily available on site at low cost. If some materials are not available, they have to be replaced with others having the above characteristics, with a reasonably moderate drop in overall efficiency.

- $\quad$ The pile driver and the floating pier should be made by very simple mechanical parts, in order to be built in a basic blacksmith workshop and replicated on site. For example, for the vertical raising of the truss the solution in hinged portions operated by the winch has been rejected, because it would involve excessive complications and machining precision.

- The pile driver and the floating pier should consist of easily transportable elements and they should be easily assembled on the site of use, therefore hand movable and not longer than $3 \mathrm{~m}$.

Pile driver

\section{General design}

The pile driver has been structurally designed, also according to the relevant Eurocodes (EN, 2007) (Figure 2).

Given the type of soil on which to operate, the piles to be used for the construction of micro-infrastructures generally are of the "suspended" type. Moreover their resistance to horizontal actions are important at least as the resistance to vertical actions. However it must be considered that the values of these last actions are far less than those generally encountered in pilings for ordinary buildings and civil works for which, moreover, the eligible permanent deformations are far lower than those tolerated in the designed micro-infrastructures.

The formulas for the calculation of the vertical lift of the piles (Davidian, 1973) are based or on the knowledge of refusal (so-called dynamic), or on knowledge of the characteristics of the soil (so-called static). The latter is also necessary for the calculation of the resistance to horizontal actions (ASABE, 2000; Giacomin et al., 2005).

Of course the refusal is unknown; the values of density, internal friction and cohesion of the soil are only vaguely conceivable. The max- imum mass of the pile is about $60 \mathrm{~kg}$ (pile $\emptyset 16 \mathrm{~cm}, \mathrm{l}=6 \mathrm{~m}$ ). Given these uncertainties, the pile driver is designed so that both the mass of the hammer and the stroke are largely alterable in a simple manner. For the mass of the hammer actually realized a value is adopted to allow the movement by hand.

When the pile driver has to be actually used, being very unlikely to have reliable data on soil characteristics, it could be necessary to drive some attempt piles, in order to develop the optimal values of the mass of the hammer and the stroke.

\section{Relevant design specifications}

The structure consists of 4 main pieces which can be assembled together on-site: the chassis CH1 (approximately: length $=3.00 \mathrm{~m}$, mass $=100 \mathrm{~kg}$ ), the lower truss TR1 (approximately: length=2.50 m, mass $=70 \mathrm{~kg}$ ), the middle truss TR2 (approximately: length $=2.50 \mathrm{~m}$, mass $=60 \mathrm{~kg}$ ), which can be replicated in order to increase the stroke of the hammer, and the upper truss TR3 (approximately: length $=2.70 \mathrm{~m}$, mass $=70 \mathrm{~kg}$ ). 0 ther removable components are the hammer (rough mass $70 \mathrm{~kg}$ ) and the Pile Ties (rough mass $10 \mathrm{~kg}$ ). The mass of the hammer can be increased by applying steel sheets, if necessary.

The chassis consists of a tube frame and rests on 4 adjustable bases of the type used for scaffolds. Four supports are welded to the frame by 4 castor wheels. Four coach screws are used for the connection of the base plate of the element TR1. The coach screws are fitted with double nut and lock nut in order to make adjustable the slant of the truss with respect to the chassis. The hoist winch is bolted to the chassis; to the chassis the pulley for the transmission of the hoist rope is also connected. The pulley is equipped with a tube-frame in order to prevent the derailment of the rope. This transmission can be avoided joining directly the hoist rope to the pulley at the head of the truss, thereby reducing the friction of the system. The bending moment is minimized acting on the truss. In the realized configuration the winch has a reduction ratio of about $1 / 6$.

The 3 elements TR1, TR2, TR3, which constitute the truss, were constructed using prefabricated elements, to which the rail of the hammer stroke and the pulleys on the head have been applied. It was decided to use these prefabricated elements in order to reduce the process-

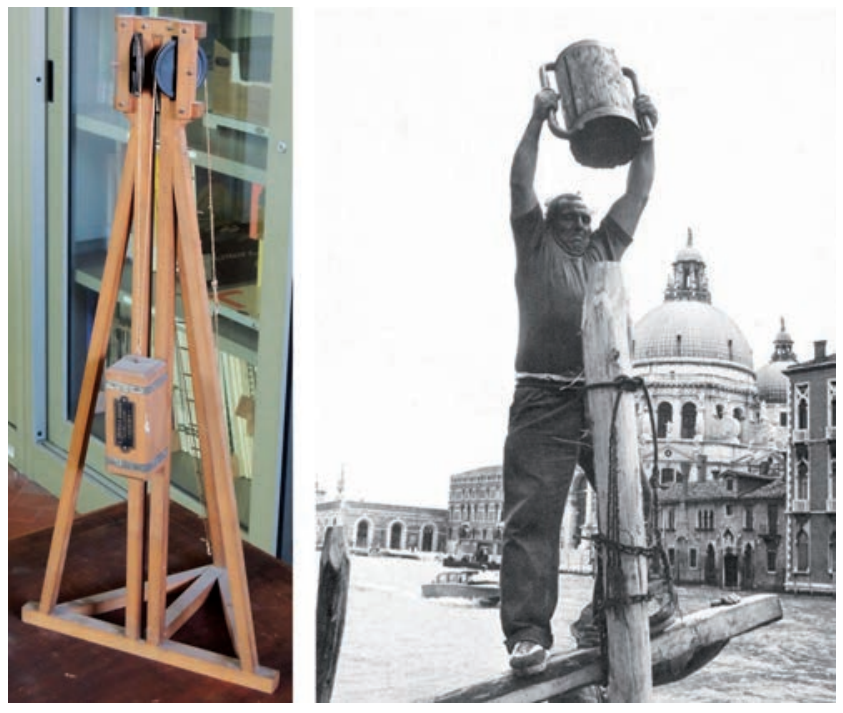

Figure 1. Pile driver model, owned by the GESAAF, and a present-day hand operated pile driver in Venice.

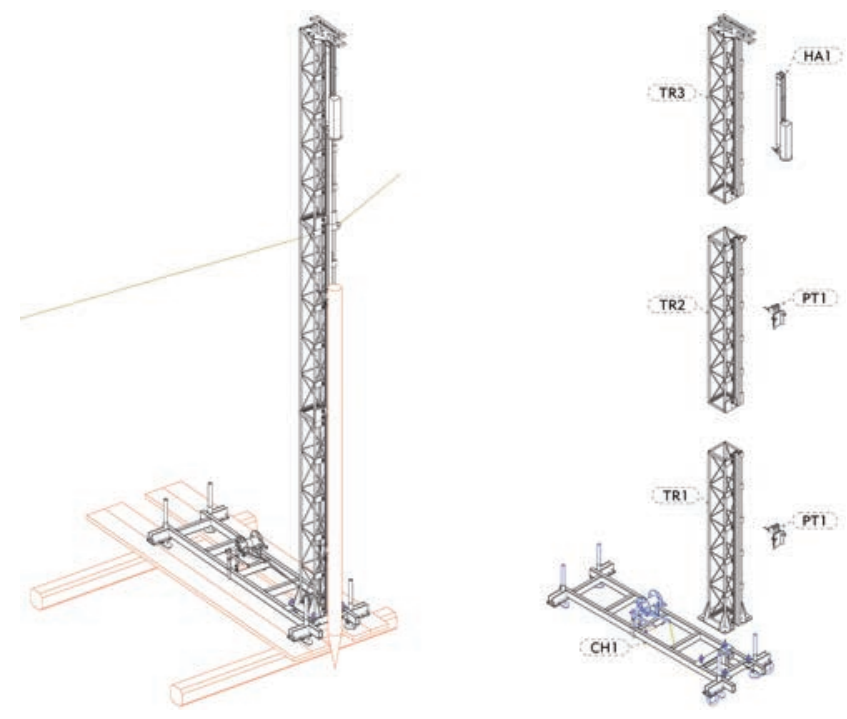

Figure 2. The pile driver on ground, and its major components. 
ing times. However, the implementation of these elements in the workshop presents no difficulties. In order to obtain a perfectly rectilinear rail, consisting in a IPE80 section bar, this was applied on the truss fully assembled and horizontally disposed. To guarantee the easiness and the precision of the mutual coupling of the elements in the on-site assembly phase, appropriate slide elements have been affixed. The pulleys on the head are equipped with a tube-frame in order to prevent the derailment of the rope. For the pulleys normal wheels for sliding gates were used.

The hammer and the pile-ties run on the flange of the IPE section bar, lubricated with grease, by means of steel sliding blocks sufficiently long and loose as to avoid any jamming.

For the uplifting chains and steel ropes anchored to stakes driven into the ground with a mallet are used. Such stakes are expressly designed equipped with variable height fastening. Lifting is implemented by means of a griphoist. The horizontal actions on the pile driver (mainly wind) are countered by two stays in synthetic fiber fitted with hoist and cam-cleats. The lifting rope is of the type with great flexibility and small elongation under stress (sheet rope).

\section{Construction}

In order to demonstrate that the pile driver, as well as designed, can be built by unskilled personnel in small blacksmith workshops, it was completely built in the workshop held by GESAAF, by staff belonging to the Department, then by non-professionals of mechanical constructions. The workshop is equipped with the following major equipment: drill press for holes up to $\emptyset 16 \mathrm{~mm}$, miter saw for elements having transverse dimension not exceeding $100 \mathrm{~mm}$, wire welding and electrode welding, lathe. All equipment is of usual level (Figure 3).

\section{Piles preparing for driving}

The head of the pile must be circled with a frettage to avoid splitting under the blows of the hammer. A simple method, specifically designed, consists in fixing chain, strongly tightened with a bolt, located few centimeters away from the upper surface (Figure 4).

The tip of the pile must be formed so that it is as much as possible aligned with the axis of the pile. If the pile is constituted by green wood the tip can be hardened by subjecting it to a strong heating in order to evaporate moisture, however without coming to burn.

\section{Floating pier}

\section{Design}

The floating pier has been structurally designed, also according to the relevant Eurocodes (EN, 2007).

The floating pier was conceived as a 3D truss which can be assembled on-site, backed into the water from empty oil barrels, having the capacity of $216.5 \mathrm{l}$ (ISO, 2002) (Figure 5).

The elementary components of the floating pier have dimensions 1210x910x460 mm and a mass ranging from $35 \mathrm{~kg}$ to $42 \mathrm{~kg}$; therefore they are movable by hand.

To avoid that the entire floating pier has to be launched, assembly must take place in water. For this purpose a system of connection joints has been designed, so that the bolting must be performed only in the part of the structure that emerges above the surface of the water. Above the floating reticular structure a deck of wood boards has to be placed.

The floating pier could not be built in Firenze because the shipping costs would have far exceeded the cost of construction. However, the extreme simplicity of the structure allows that it is made in-situ with ease and economy.
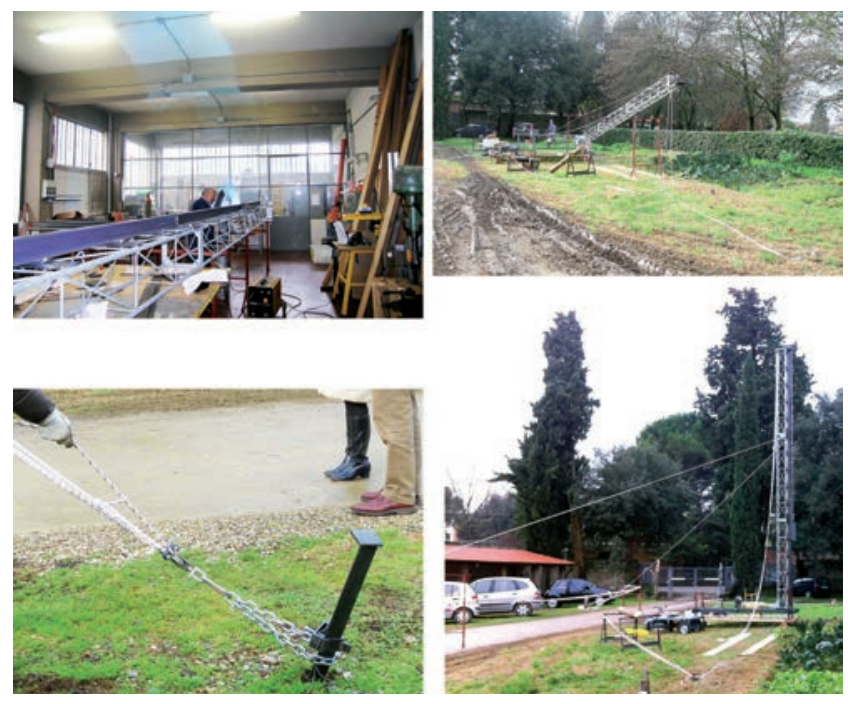

Figure 3. Pile driver under construction; uplifting; stays hooking system, and pile driver in working position.

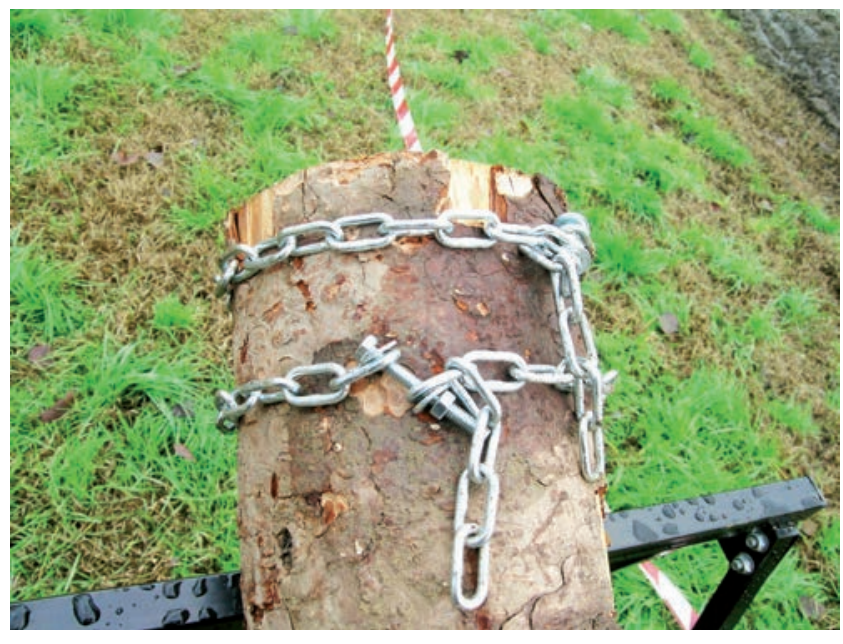

Figure 4. Pile head frettage.
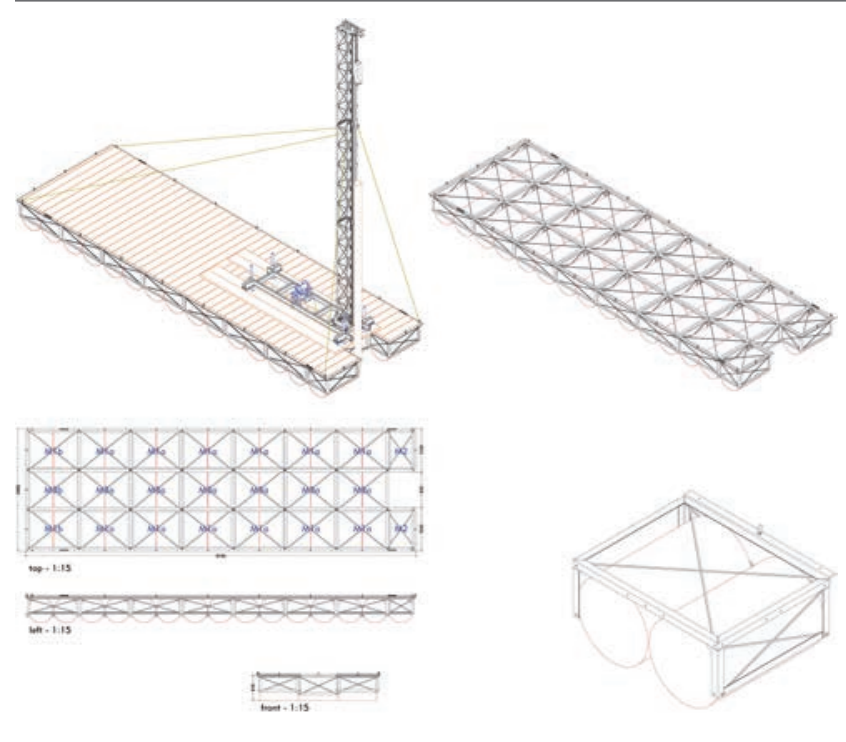

Figure 5. The pile driver on the floating pier; the complete 3D Truss; pile driver views; a modular component of the floating pier. 


\section{Results}

In order to test the proper functioning and effectiveness of the pile driver, it has been assembled and positioned within the competence area of the GESAAF. The soil on which the test was carried out has physical and mechanical characteristics different from those on which the pile driver should carry out his work. However, the trial was intended to establish the correctness of the overall functioning of the mechanism, and a generic indication of its effectiveness.

\section{Conclusions}

All the activities were carried out with satisfactory results. The effectiveness of the machine was verified, and in particular it was demonstrated that the pile driver can be placed and removed with the use of only 3 people. In essence the tests give reasonable assurance that the tools can be effectively used in the expected places and conditions of employment.

\section{References}

[1] Alwash, A., Alwash, S., and Cattarossi, A. (2008). Iraq's Marshlands - Demise and the Impending Rebirth of an Ecosystem. Baghdad: Iraq Foundation.

[2] AMAR International Charitable Foundation (2001). The Iraqi Marshlands. AMAR International Charitable Foundation.

[3] ASABE - American Society of Agricultural and Biological Engineers (2000, October). ANSI/ASAE 486.1 - Shallow Post Foundation Design. USA: ASABE -American Society of Agricultural and Biological Engineers.

[4] Barbari, M., Conti, L., Monti, M., Pellegrini, P., Rossi, G., Simonini, S., and Sorbetti Guerri, F. (2012). Antropizzazioni decostruibili per il non-consumo del territorio rurale - Parte I: dallo sviluppo sostenibile alle antropizzazioni decostruibili. L'Edilizia Rurale tra Sviluppo Tecnologico e Tutela del Territorio. Firenze: AIIA Associazione Italiana di Ingegneria Agraria.

[5] Barbari, M., Conti, L., Monti, M., Pellegrini, P., Rossi, G., Simonini, S., and Sorbetti Guerri, F. (2012). Antropizzazioni decostruibili per il non-consumo del territorio rurale - Parte II: progettazione per la decostruibilità. L'Edilizia Rurale tra Sviluppo Tecnologico e Tutela del Territorio. FIRENZE: AIIA - Associazione Italiana di Ingegneria Agraria.

[6] Berge, B. (2001). Ecology of Building Materials. Oxford, UK: Architectural Press.

[7] CBD, Convention on Biological Diversity. (2004). The CBD Guidelines on biodiversity and tourism development. Montreal, Canada: Secretariat of the Convention on Biological Diversity.

[8] CBD, Convention on Biological Diversity; UNEP, United Nations Environment Programme. (2007, Feb). Users' Manual on the CBD Guidelines on Biodiversity and Tourism Development. Montreal, Canada: Secretariat of the Convention on Biological Diversity.

[9] Davidian, Z. (1973). Pali e fondazioni su pali. Bologna: C.E.L.I.
[10] Eden Again (2003). Building a Scientific Basis for Restoration of the Mesopotamian Marshlands. Baghdad: The Iraq Foundation.

[11] EN (2007). EN 1993-1-1 - Eurocode 3 - Design of steel structures.

[12] Giacomin, A., Monti, M., Pellegrini, P., and Sorbetti Guerri, F. (2005). Resistenza alle azioni orizzontali di pali in legno infissi nel terreno. Verifiche sperimentali. L'ingegneria agraria per lo sviluppo sostenibile dell'area mediterranea. Catania: AIIA.

[13] ISO - International Organization for Standardization (2002). ISO 15750-2:2002. Packaging — Steel drums — Part 2: Non-removable head (tight head) drums with a minimum total capacity of $212 \mathrm{l}, 216,5 \mathrm{l}$ and $230 \mathrm{l}$.

[14] IWMI - International Water Management Institute (2010). Using wetlands sustainably. Colombo: International Water Management Institute. doi:10.5337/2010.231

[15] Kubba, S. (2011). The Iraqi Marshlands and the Marsh Arabs. Reading, UK: Ithaca Press.

[16] MA, Millennium Ecosystem Assessment. (2005). Ecosystems and human well-being: wetlands and water synthesis. Washington, DC, USA: World Resources Institute.

[17] Niemann, G. (1967). Elementi di macchine. Springer.

[18] Ramsar Convention on Wetlands (1971, Feb 2). The Convention on Wetlands text, as originally adopted in 1971. Retrieved from http://www.ramsar.org/cda/en/ramsar-documents-texts-convention-on-20708/main/ramsar/1-31-38\%5E20708_4000_0_

[19] Ramsar Convention on Wetlands (2008, Oct-Nov). The Changwon Declaration on human well-being and wetlands. "Healthy wetlands, healthy people". Changwon, Republic of Korea.

[20] Ramsar Convention on Wetlands (2010). The Ramsar Handbooks for the wise use of wetlands (IV ed.). Gland, Switzerland: Ramsar Convention Secretariat.

[21] Ramsar Convention on Wetlands; UNWTO, World Tourism Organization (2012). Destination wetlands: supporting sustainable tourism. Secretariat of the Ramsar Convention on Wetlands, Gland, Switzerland, \& World Tourism Organization (UNWTO), Madrid, Spain.

[22] Russi, D., ten Brink, P., Farmer, A., Badura, T., Coates, D., Forster, J., and Davidson, N. (2013). The economics of ecosystems and biodiversity for water and wetlands. London, UK: IEEP, Institute for European Environmental Policy, GB; Ramsar Convention Bureau; Wetlands International; CBD, Convention on Biological Diversity; IUCN, International Union for Conservation of Nature; UFZ, Helmholtz Zentrum für Umweltforschung, DE.

[23] Shine, C., and de Klemm, C. (1999). Wetlands, Water and the Law. Using law to advance wetland conservation and wise use. Gland, Switzerland, Cambridge, UK and Bonn, Germany: IUCN, International Union for Conservation of Nature.

[24] UNEP, and Partow, H. (2001). The Mesopotamian Marshlands: Demise of an Ecosystem. Nairobi, Kenya: United Nations Environment Programme - Division of Early Warning and Assessment.

[25] United Nations - World Commission on Environment and Development (1987). Our Common Future.

[26] United Nations (1992, May 22). Convention on Biological Diversity. Nairobi, KENYA.

[27] USAID - United States Agency for International Development (2004). The Iraq Marshlands Restoration Program. USAID. Retrieved from www.usaid.gov/iraq. 